\title{
Development of a Neuropsychological Rehabilitation Program for Executive Functions in Students with Developmental Dyslexia
}

\author{
Ricardo Franco de Lima', Cíntia Alves Salgado Azoni², Sylvia Maria Ciasca1 \\ ${ }^{1}$ Department of Neurology, State University of Campinas-UNICAMP, Campinas, Brazil \\ ${ }^{2}$ Departament of Speech and Language Pathology, Federal University of Rio Grande do Norte-UFRN, Natal, Brazil \\ Email: ricardolima01@yahoo.com.br
}

How to cite this paper: de Lima, R. F., Azoni, C. A. S., \& Ciasca, S. M. (2017). Development of a Neuropsychological Rehabilitation Program for Executive Functions in Students with Developmental Dyslexia. Psychology, 8, 1110-1128.

https://doi.org/10.4236/psych.2017.88072

Received: January 17, 2017

Accepted: June 9, 2017

Published: June 12, 2017

Copyright $\odot 2017$ by authors and Scientific Research Publishing Inc. This work is licensed under the Creative Commons Attribution International License (CC BY 4.0).

http://creativecommons.org/licenses/by/4.0/ (c) (i) Open Access

\begin{abstract}
Neuropsychological rehabilitation and self-regulated learning models are commonly used in intervention programs for students with learning disorders. However, systematic programs with this same objective are scant. Here we describe the development and evaluation of a neuropsychological rehabilitation program for the executive functions of students with dyslexia. The program is separated in stages comprising: theoretical basis foundation, definition of session structures and development of support material, evaluation by three expert judges, revision, and elaboration of the final version. The final program consists of thirty sessions divided into four modules, including (1) psychoeducation; (2) orientation for parents and teachers; (3) executive functions applied to study competencies; and (4) executive functions applied to reading comprehension. Judges evaluated 53 items associated with theoretical basis, clinical principles, support material and modules. The items were distributed on the Likert scale as inadequate (0), partially adequate (1), and adequate (2). Five items had an agreement index of $67 \%$, the rest had $100 \%$. The Kappa coefficients were "excellent" (theoretical basis, clinical principles and orientation module) or "satisfactory" (support materials, psycho-education modules, competencies and reading). Suggestions from the judges were incorporated into the program's final version. A discussion of our results sheds light on the possible implications of the program for the stimulation of executive functioning in developmental dyslexia.
\end{abstract}

\section{Keywords}

Dyslexia, Executive Functions, Self-Regulated Learning, Intervention, Neuropsychological Rehabilitation 


\section{Introduction}

Developmental dyslexia (DD) is a specific learning disability characterized by difficulties in decoding words and comprehending written language, resulting from phonological deficits (Lyon, Shaywitz, \& Shaywitz, 2003). Cognitive domains, such as executive functions (EF), may affect abilities that usually show deficit in DD (Sesma et al., 2009). Similar effects are observed with school performance in general (Visu-Petra, Cheie, Benga, \& Miclea, 2011; Abreu et al., 2014) and study competencies, such as completing homework, studying for tests, efficiently using time, taking notes in the classroom and keeping them organized (Meltzer \& Krishnan, 2007).

Conceptually, EF are defined within a multidimensional construct representing a set of abilities and top-down cognitive processes that help the individual autonomously engage in activities with specific objectives (Diamond, 2013). From an operational perspective, the EF participate in every phase of a task until its completion: defining goals, planning stages, prioritizing, organizing, selecting strategies, monitoring one's own performance, recognizing mistakes, having cognitive flexibility to change courses of action, controlling attention and interferences, and evaluating one's own performance (Meltzer, 2007; Meltzer \& Krishnan, 2007; Kaufman, 2010; Bombín-Gonzalez et al., 2014).

Studies show that individuals with DD have different components of the EF altered, such as the working memory, inhibition control, flexibility, use of strategies and fluency (Lima, Salgado-Azoni, \& Ciasca, 2013; Moura, Simões, \& Pereira, 2014; Varvara, Varuzza, Sorrentino, Vicari, \& Menguini, 2014). Despite a body of evidence relying on evaluations, few researchers have applied intervention strategies on this population in which the focus was on EF in the clinical and/or educational contexts.

In a clinical perspective, neuropsychological rehabilitation (NR) studies of dyslexia emphasize on computerized stimulation of cognitive domains, such as visual processing and attention, and have shown restricted results to improvements to word and text reading (Lorusso, Facoetti, Paganoni, Pezzani, \& Molteni, 2006; Lorusso, Facoetti, \& Bakker, 2011). By contrast, the self-regulated learning constitutes the most often described model regarding intervention for students with learning difficulties (Zimmerman, 2002; Pintrich, 2000; Rosário, 2004), and represents the degree of student independence in dealing with educational demands, from metacognitive, motivational and behavioral points of view (Zimmerman, Bonner, \& Kovach, 2002; Liew, 2011; Bjork, Dunlosky, \& Kornell, 2013). Specific process of self-regulated learning linked to reading comprehension include establishing objectives, activation of background knowledge, following rules, using adequate cognitive and metacognitive strategies, monitoring one's own performance, time management, seeking help when necessary, selfefficacy, motivation, identifying factors that affect learning, and experiencing satisfaction with one's own efforts (Schunk \& Ertner, 2000; Klingner, Vaughn, \& Boardman, 2007; Cirino et al., 2016).

This model uses the strategic instruction focused on different EF processes as 
an intervention procedure for the study and academic skills (Meltzer, 2007; Meltzer \& Krishnan, 2007; Dawson \& Guare, 2010; Cirino et al., 2016). Meltzer (2007) developed a strategy teaching program aimed at six areas, including prioritization, organization, working memory, flexibility, self-monitoring, and emotional self-regulation. These strategies are applied to different study competencies: time management, long-term projects, homework, test taking, math problem solving, written language, reading comprehension, summarizing and note taking. Dawson and Guare (2010) also developed an EF intervention proposal, through which students are instructed about strategies, and receive support from teachers until becoming self-sufficient in the use of such strategies. Adaptations to the home and school environments are also recommended.

The self-regulated strategy development (SRSD) model (Graham e Harris, 1996) has been successful in interventions targeting reading comprehension (Mason, 2004; Mason, Reid, \& Hagaman, 2012) and writing (Troia \& Graham, 2002; García-Sánchez \& Fidalgo-Redondo, 2006) for students with learning disabilities (LD). The SRSD is a training approach that combines explicitly instruction strategies and self-regulation. Strategy instruction involves six stages: 1) developing and activating the background knowledge; 2) discussing the strategy; 3 ) modeling the strategy; 4) memorizing the strategy; 5) lending support to the strategy; and 6) independent performance. Thus, the adults (parents, teachers and therapist) systematically transfer control and responsibility over the use of the strategy to the student (Mason et al., 2012; Harris, Graham, Mason, \& Friedlander, 2012).

There are evidences that interventions to promote the executive functioning and self-regulated learning are effective to reducing the deficits of students with DD and learning disabilities (Antoniou \& Souvignier, 2007; Berkeley, Mastropieri, \& Scruggs, 2011; Mason, 2013; Zentall \& Lee, 2012). For instance, Mason (2004) compared the effects of two approaches of intervention for reading comprehension in thirty-two 5th-grade students with reading disabilities. The first type was the TWA technique (Think before reading, think while reading, think After reading) taught by SRSD model and the second approach was the technique of reciprocal questioning (RQ), according to the "cooperative ReQuest" procedures. The results showed that the TWA technique was more effective to promote statistically significant improvements in five oral measures related to reading comprehension: identifying the main idea, summary, oral retell quality, oral retell information units, oral retell main ideas.

Meta-analyses focused on interventions for the improvement of reading comprehension with this population point to the efficacy of different strategies: the activation of previous knowledge; prior training in words and key concepts; training in text structure, such as the use of history maps; use of graphic organizers and conceptual maps; teaching monitoring strategies, such as mental images; teaching summary and mnemonic strategies; use of questionings before, during and after the text (Gersten, Fuchs, Williams, \& Baker, 2001; Roberts, Torgesen, Boardman, \& Scammacca, 2008; Edmonds et al., 2009; Solis et al., 
2012).

Regarding intervention program planning for $\mathrm{DD}$, a few practices have yielded better results (Edmonds et at., 2009; Kim, Linan-Thompson, \& Misquita, 2012; Solis et al., 2012): 1) interventions in up to 70 sessions; 2) sessions between 30 and 120 minutes; 3 ) a minimum of $23 \mathrm{hr}$ in total; 4) individual interventions or in pairs are more efficient than group interventions; 5) preference for narrative texts; 6) among reading components, comprehension is more often approached and associated to vocabulary; 7) interventions conducted by a researcher with a defined script have greater impact on comprehension; and 8) interventions based on multiple strategies have stronger effects.

In face of the need for DD intervention programs targeting cognitive domains other than language, the objective of the present work was to describe the development and evaluation of a novel neuropsychological rehabilitation program for the EF in students with DD.

\section{Method}

A neuropsychological rehabilitation program (NRP) was designed to promote the executive functioning and self-regulated learning. The PNR is aimed at adolescents with dyslexia diagnosis and who have basic skills in decoding words. The phases in the elaboration are found in Figure 1. Initially a search in the international literature was conducted to identify the main theoretical models used for interventions in the areas of neuropsychological rehabilitation and self-regulated learning. Subsequently, NRP structure was developed based in selection of the EF strategies that would be instructed and construction of the materials.

Inter-judge analysis usually requires from three to five specialists (HernándezNieto, 2002). In the present work, the analysis of NRP material was conducted by three judges specialized in: clinical psychology and neuropsychological intervention; clinical psychology and education; and speech and language pathology and intervention in written language. Selection criteria included expertise in the clinical area and research experience in the areas of neuropsychology and education.

Judges received a copy of the NRP application notebook and protocol containing instructions and parameters to guide the analysis. Parameters included theoretical basis, clinical principles, materials and modules. Each parameter contained a determined number of items organized in the Likert scale as inadequate (0), partially adequate (1), and adequate (2). Each judge evaluated 53 items (Table 1), in cases where items were evaluated as 0 or 1 , explanations were included to allow study authors to revise their work.

After receiving protocols, items were tabulated for statistical analysis. We calculated agreement index (AI) among judges, expressed as percentages, for each item belonging to evaluated parameters. Agreement was considered adequate starting at $80 \%$ (Pasquali, 2013). In addition, Kappa ( $k$ ) coefficient was calculated to test the degree of agreement. Classification uses for this coefficient was $<.40$, poor; $.40-.75$, satisfactory to good; >.75, excellent (Fleiss, 1981). After 
analysis by judges, the NRP was revised to compose the final version.

\section{Results}

\subsection{Phase 1-Theoretical Foundation}

Models selected to form the theoretical foundation of the NRP were chosen from the clinical (neuropsychological rehabilitation) and educational (self-regulated learning) areas. The clinical model was based in the principles suggested by Wilson $(2008$; 2013) for NR. The development of tasks and the organization of sessions that specifically targeted EF rehabilitation took into account the clinical principles suggested by Sohlberg and Mateer (2010) and work developed by Meltzer (2007), Kaufman (2010), as well as Dawson and Guare (2010). We selected educational models of self-regulated learning based on Printich (2000),

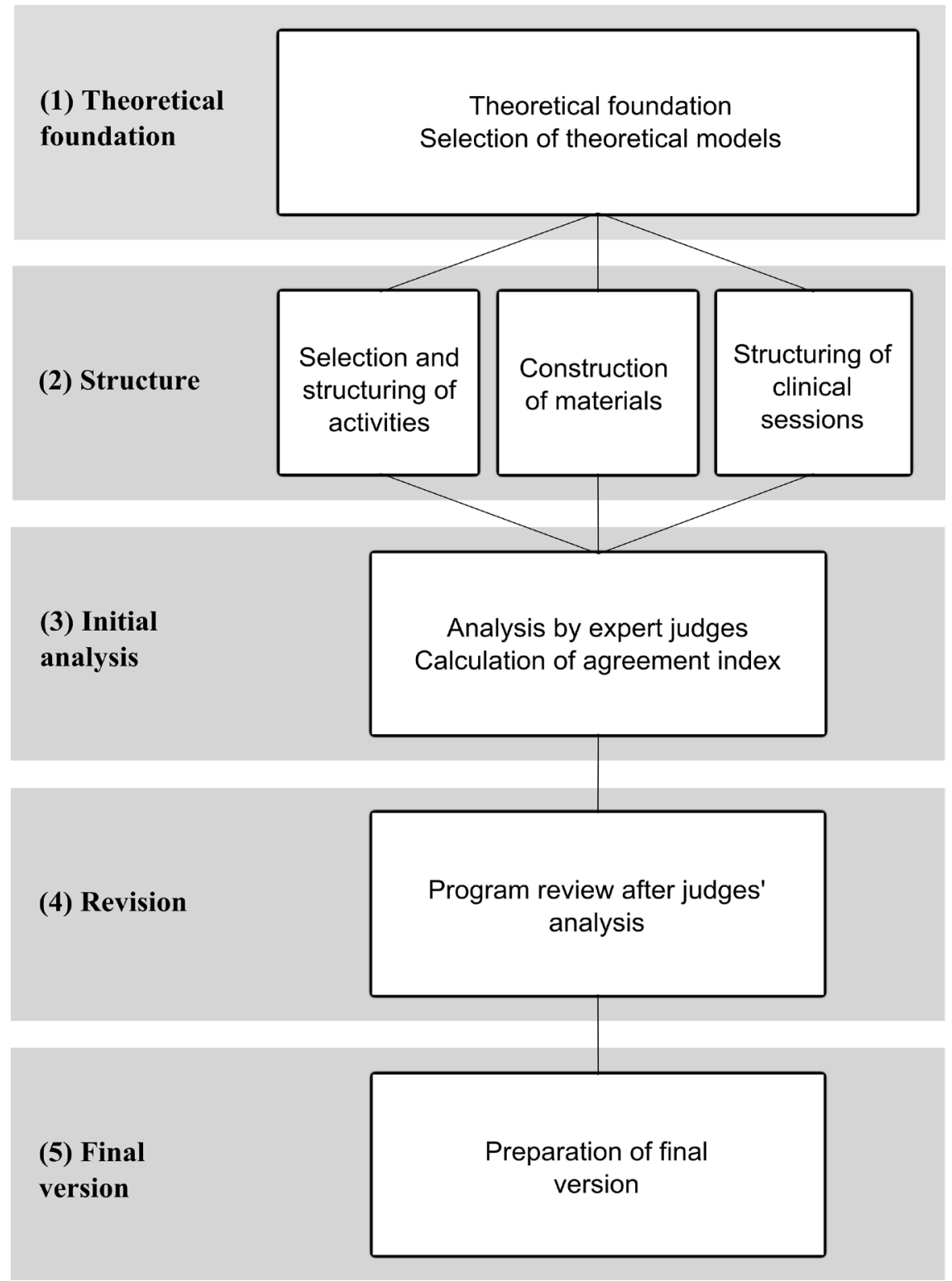

Figure 1. Flowchart describing the stages involved in the development of the NRP. 
Table 1. Evaluation parameters and number of items.

\begin{tabular}{cc}
\hline Parameters & Items \\
\hline Theoretical basis & 09 \\
Clinical principles & 06 \\
Materials & 06 \\
Module 1. Psychoeducation & 08 \\
Module 2. Orientation & 08 \\
Module 3. Executive functions applied to study competences & 08 \\
Module 4. Executive functions applied to reading \\
comprehension
\end{tabular}

Zimmerman (2002) and Rosário (2004). The process of learning EF strategies was based on a model of explicit instruction on kinds of knowledge (declarative, conditional and procedural), and in the SRSD model (Graham \& Harris, 1996; Mason et al., 2012; Harris et al., 2012). To guide our interventions in reading comprehension, we applied the metacognition model of Flavell (1979). The process of learning strategies associated with reading comprehension also followed the stages defined in the SRSD (Graham \& Harris, 1996; Mason et al., 2012; Harris et al., 2012). In summary, the clinical principles underlying the NRP are shown in Table 2.

\subsection{Phase 2-Structure}

Once the selection of theoretical models was finalized, the NRP material was delineated containing: 1) Manual for the application of NRP composed of: theoretical foundations; program description; objectives; target public; summary of theoretical approaches; explanation on the structure of sessions; clinical principles; description and instruction for the use of materials; description of each session (time, clinical objectives, materials, important EF components, as well as applied strategies-cognitive or metacognitive); 2) Specific materials to be used during sessions: informative materials (slides, videos, and folders for explicit instruction); session materials (slides with session contents, calendar, objectives, to-do list, evaluation form, learned strategy list, spreadsheet for self-monitoring the reading comprehension in the computer); record-keeping forms (materials for the annotation of psychoeducation sessions, orientation and sessions with the patient); games that promote daily activity planning, study environment organization, and review EF strategies applied to study competencies; strategy support material (calendar for the adequate use of time, planning material for taking exams, support material for homework strategies, studying for exams and reading comprehension, conceptual maps, diagrams and vocabulary map); and cards containing a summary of each strategy adopted.

The designed NRP was composed of 30,60-minute sessions, to be conducted up to twice a week, individually. Frequency of sessions was defined taking into account clinical applicability and time required for the patients to exercise the strategies in different contexts. We estimated that the interventions, as designed, 
Table 2. Clinical principles of the neuropsychological rehabilitation program.

\begin{tabular}{|c|c|}
\hline Principles & Description \\
\hline $\begin{array}{l}\text { Clinical relationship } \\
\text { and therapeutic bond }\end{array}$ & $\begin{array}{l}\text { Stimulation of EF and development of autonomy for the use of } \\
\text { strategies. } \\
\text { Prioritization of the use of questions and debates. } \\
\text { Progressive transfer of control over tasks to the patient. }\end{array}$ \\
\hline Training model & $\begin{array}{l}\text { Explicit training of EF strategies for different school demands. } \\
\text { Scaffoldings (Mason et al., 2012): } \\
\text { - Content-approach themes in an encouraging manner to teach } \\
\text { strategy; use daily situations; teach step by step with increasing dif- } \\
\text { ficulty levels; } \\
\text { - Tasks—task execution control is gradually transferred to the pa- } \\
\text { tient during the sessions; } \\
\text { - Materials—external supports (hints, cards, and graphs) are used to } \\
\text { help the patient in the use of strategies and should be gradually } \\
\text { removed. }\end{array}$ \\
\hline Self-regulation & $\begin{array}{l}\text { - Goal setting - focus on efforts and progress monitoring; } \\
\text { - Self-monitoring - increasing awareness of one's own performance; } \\
\text { - Self-instructions-use of language to mediate behavior: goal } \\
\text { setting, focus, planning, strategy use, self-evaluation, support own } \\
\text { performance and self-reinforcement. }\end{array}$ \\
\hline External support & $\begin{array}{l}\text { Used in sessions and other contexts to help organize information and in } \\
\text { mnemonic strategies. Types: figures, posters, checklists, informative } \\
\text { material, videos, summary cards, post-its, white-boards, calendars } \\
\text { among others. }\end{array}$ \\
\hline $\begin{array}{l}\text { Environmental } \\
\text { control }\end{array}$ & $\begin{array}{l}\text { Adoption of environmental control actions: psychoeducational modules } \\
\text { and orientation for parents and teachers; orientation about study } \\
\text { environment; routine incorporation; use of support material at home } \\
\text { and in school; encouraging parental involvement. }\end{array}$ \\
\hline $\begin{array}{l}\text { Reinforcement } \\
\text { system }\end{array}$ & $\begin{array}{l}\text { Use of different reinforcement systems to facilitate learning of EF } \\
\text { strategies in the clinical environment and other contexts. The procedure } \\
\text { is mediated by the therapists and aims at developing self-reinforcement. }\end{array}$ \\
\hline Ecological value & Strategies must have a link to school and reading situations. \\
\hline
\end{tabular}

would span 6 months. Patients should be oriented to use a folder during sessions, where they will keep materials made available by the therapist. The folder should be used in the family and school contexts for the exercise of strategies. Parents as well as teachers can keep track of the NRP progress through the materials in the folder. Sessions were grouped in four modules: 1) Psychoeducation (PSYCHOEDU) with parents, teachers and patients-four sessions that may be conducted in parallel and aim at providing information on DD and the NRP. In addition to program information, students will also learn about how the program works, session models and the materials that will be used; 2) Orientation (ORIENT)-eight sessions, being four with parents and four with the school, distributed throughout the intervention process, that may be conducted in parallel with patient sessions. The objective of this module is to establish a system of reinforcement, to create conditions of the reinforce for target behaviors (e.g. increase the study time, use the calendar, read more, among others), to guide ch- 
anges to the study environment, to monitor strategy implementation and to answer questions. The ORIENT will be based in objectives defined among therapist, parents and school; 3) Executive functions applied to study competencies (EFCOM)-eight sessions that promote EF strategies applied to time management, organization of environment/materials, homework, note taking, and preparing for exams; 4) Executive functions applied to reading (EFRE)-ten sessions that promote EF strategies that help in the comprehension of narrative text. We selected 30 narrative texts that should be used in learning comprehension strategies and exercising their use. Patient performance should be monitored at each session by the Cloze test.

The structure of sessions in each module was based in models of self-regulated learning (Zimmerman, 2002; Pintrich, 2000; Rosário, 2004) and in the SRSD (Graham \& Harris, 1996; Harris et al., 2012) as shown in Table 3. In general, for strategy learning modules (EFCOM and EFRE), sessions are initiated (Planning) reviewing subjects discussed in the previous session and checking homework. Immediately after, the therapist should introduce the theme that will be discussed (e.g., preparing for exams or reading comprehension), the meeting agen$\mathrm{da}$, and session goals using materials available in the computer. The therapist should survey the patient's prior knowledge of the session theme. The patient should be encouraged to verbally expose his knowledge, and the therapist should mediate, organizing information in writing. In the following stage (Execution), depending on the level of proficiency of the patient in a given EF strategy, the therapist should work on training, modeling, memorization, guided practice or independent practice (according to phase of SRSD). At this stage, the therapists should use materials that were specifically tailored for each goal: slides and videos for explicit instruction, games and tasks for the exercise of strategies, and summary cards to be kept in the patient's folder. At the final stage (Evaluation), the therapist should recapitulate the theme discussed during the session; there is an assessment of goals achieved, using the specific form; the patient is encouraged to evaluate his comprehension and learning of the strategies through a specific form; homework is assigned and listed in the to-do list to be kept in the patient's folder.

\subsection{Phases 3, 4 and 5-Initial Analysis, Revision and Final Version}

In general, the agreement between judges 1 and 2 was $94 \%$, between 1 and 3 it was $94 \%$, and between 2 and 3, it was $92 \%$. These results suggest that the general evaluation was classified as satisfactory (Pasquali, 2013).

More specifically, the AI for each item analyzed are shown in Table 3 and Table 4. The AI for items concerning theoretical basis and clinical principles was $100 \%$. Regarding materials, the agreement was moderate (67\%) for graphic aspects and clarity of descriptions in the application notebook. Judge 3 suggested that the material should have longer explanations about the figures, ways in which reading comprehension parameters were obtained, and types of knowledge (declared, conditional, procedural) (Table 4). 
Table 3. Clinical model of session in the neuropsychological rehabilitation program (NRP).

\begin{tabular}{|c|c|c|c|}
\hline \multirow[t]{2}{*}{ Acronym } & \multicolumn{3}{|c|}{ Modules } \\
\hline & PSYCHOEDU & ORIENT & EFCOM and EFRE \\
\hline \multirow{3}{*}{$\begin{array}{l}\text { Before: } \\
\text { Planning }\end{array}$} & $\begin{array}{l}\text { Context } \\
\text { - Rapport. }\end{array}$ & $\begin{array}{l}\text { Context } \\
\text { - Review prior session. }\end{array}$ & $\begin{array}{c}\text { Context } \\
\text { - } \quad \text { Review prior session; } \\
\text { - } \quad \text { Evaluate homework. }\end{array}$ \\
\hline & \multirow{2}{*}{$\begin{array}{l}\text { Agenda } \\
\text { - Present session agen- } \\
\text { da. }\end{array}$} & \multirow[t]{2}{*}{$\begin{array}{l}\text { Agenda } \\
\text { - Present session agen- } \\
\text { da. }\end{array}$} & $\begin{array}{l}\text { Objectives } \\
\text { - } \quad \text { Present theme; } \\
\text { - } \quad \text { Session agenda; } \\
\text { - } \quad \text { Session goals. } \\
\end{array}$ \\
\hline & & & $\begin{array}{c}\text { Raise background } \\
\text { knowledge }\end{array}$ \\
\hline \multirow{4}{*}{$\begin{array}{l}\text { During: } \\
\text { Execution }\end{array}$} & Raise expectations & $\begin{array}{c}\text { Summary of sessions and } \\
\text { strategies }\end{array}$ & $\begin{array}{c}\text { Instruction and } \\
\text { discussion about strategy }\end{array}$ \\
\hline & $\begin{array}{l}\text { Information and } \\
\quad \text { instruction: } \\
\text { - } \quad \text { Dyslexia, intervention } \\
\text { program; } \\
\text { - Instruction about } \\
\text { intervention materials } \\
\text { (for patients). }\end{array}$ & $\begin{array}{l}\text { Support } \\
\text { - Support offered by } \\
\text { family and school in } \\
\text { the use of materials } \\
\text { and strategies. }\end{array}$ & Strategy Modeling \\
\hline & $\begin{array}{c}\quad \text { Objectives: } \\
\text { - Initial goal setting; } \\
\text { - } \quad \text { Definition of a }\end{array}$ & $\begin{array}{l}\text { Goals and reinforcement } \\
\text { - Monitoring objective } \\
\text { and defining others; } \\
\text { - Monitoring }\end{array}$ & $\begin{array}{l}\text { Strategy memorization } \\
\text { Guide practice with or } \\
\text { without support materials }\end{array}$ \\
\hline & system. & $\begin{array}{l}\text { effectiveness of } \\
\text { reinforcements. }\end{array}$ & Independent practice \\
\hline After: & \begin{tabular}{l}
\multicolumn{1}{c}{ Closing } \\
- $\quad$ Session summary; \\
Handing out folder \\
with explanations \\
about the NRP \\
(parents/school).
\end{tabular} & $\begin{array}{c}\text { Closing } \\
\text { - } \quad \text { Session summary; } \\
\text { - } \quad \text { Answering questions. }\end{array}$ & $\begin{array}{l}\text { Closing and evaluation } \\
\text { - Session summary; } \\
\text { - Assessing attained } \\
\text { goals; } \\
\text { - Self-evaluation; } \\
\text { - Homework. }\end{array}$ \\
\hline
\end{tabular}

Regarding the modules (Table 5), the AI was $100 \%$ for orientation items. The item "division of sessions" in psychoeducation had an AI of 67\%. Judge 1 suggested that a longer time should be dedicated to the psychoeducation of parents to facilitate compliance with the program and enhance support to children. In the EFCOM module, the AI for the item "session description" was 67\%. Judge 2 suggested that more detailed instructions should be included regarding clinical management when the patient does not complete at home the activities planned by the therapist. Finally, an AI of $67 \%$ was also obtained for the item "division of sessions" in the module EFRE. Judge 2 suggested that a greater number of sessions should be dedicated to finalizing the intervention, taking into account affective aspects. From agreement analyses, the Kappa coefficients were rated excellent for theoretical basis, clinical principles and orientation module (Kappa $1.00, \mathrm{p}<.0001$ ). The coefficients were rated satisfactory for the materials (Kappa $0.68, \mathrm{p}=0.004)$, psychoeducation, EF applied to study competencies and reading (Kappa 0.72, p = 0.002). 
Table 4. Intra- and inter-judge agreement index (\%) for the parameters: theoretical basis, clinical principles and materials.

\begin{tabular}{|c|c|c|c|c|}
\hline Theoretical basis & $\mathrm{J} 1$ & $\mathrm{~J} 2$ & J3 & AI \\
\hline 1) The program has a theoretical basis & 2 & 2 & 2 & 100 \\
\hline $\begin{array}{l}\text { 2) It is based on theoretical models described in the } \\
\text { literature }\end{array}$ & 2 & 2 & 2 & 100 \\
\hline $\begin{array}{l}\text { 3) It shows a relation between models and the way } \\
\text { sessions and activities are organized }\end{array}$ & 2 & 2 & 2 & 100 \\
\hline $\begin{array}{l}\text { 4) Sessions are based on theoretical models described in } \\
\text { the literature }\end{array}$ & 2 & 2 & 2 & 100 \\
\hline $\begin{array}{l}\text { 5) There is coherence between theoretical basis and the } \\
\text { age range that the program targets }\end{array}$ & 2 & 2 & 2 & 100 \\
\hline 6) Sessions and activities engage the EF & 2 & 2 & 2 & 100 \\
\hline $\begin{array}{l}\text { 7) Clinical model of intervention is within the scope of } \\
\text { neuropsychology }\end{array}$ & 2 & 2 & 2 & 100 \\
\hline $\begin{array}{l}\text { 8) Clinical model of intervention is connected to the } \\
\text { educational model }\end{array}$ & 2 & 2 & 2 & 100 \\
\hline $\begin{array}{l}\text { 9) Good relation between elaborated materials and } \\
\text { theoretical models }\end{array}$ & 2 & 2 & 2 & 100 \\
\hline Total $f(\%)$ & $18(100)$ & $18(100)$ & $18(100)$ & \\
\hline Clinical principles & $\mathrm{J} 1$ & $\mathrm{~J} 2$ & J3 & AI \\
\hline 10) Clinical basis & 2 & 2 & 2 & 100 \\
\hline $\begin{array}{l}\text { 11) Principles offer a clinical basis to modules and } \\
\text { sessions }\end{array}$ & 2 & 2 & 2 & 100 \\
\hline 12) Principles are related with the EF & 2 & 2 & 2 & 100 \\
\hline 13) Principles are adequate for the target age range & 2 & 2 & 2 & 100 \\
\hline $\begin{array}{l}\text { 14) Principles are adequate for target populations with } \\
\text { learning disorders or impairments }\end{array}$ & 2 & 2 & 2 & 100 \\
\hline $\begin{array}{l}\text { 15) Principles have ecological value, i.e., modules and } \\
\text { sessions can be linked to daily activities }\end{array}$ & 2 & 2 & 2 & 100 \\
\hline Total $f(\%)$ & $12(100)$ & $12(100)$ & $12(100)$ & \\
\hline Materials & $\mathrm{J} 1$ & $\mathrm{~J} 2$ & $\mathrm{~J} 3$ & AI \\
\hline 16) Adequate for the target public & 2 & 2 & 2 & 100 \\
\hline 17) Adequate for the target age range & 2 & 2 & 2 & 100 \\
\hline 18) Graphical aspects & 2 & 2 & 1 & 67 \\
\hline 19) Clear description in application notebook & 2 & 2 & 1 & 67 \\
\hline $\begin{array}{l}\text { 20) Coherence between task demands and program } \\
\text { objectives }\end{array}$ & 2 & 2 & 2 & 100 \\
\hline 21. Relation with the EF & 2 & 2 & 2 & 100 \\
\hline Total $f(\%)$ & $12(100)$ & $12(100)$ & $10(83)$ & \\
\hline
\end{tabular}

Note. J1: Judge 1; J2: Judge 2; J3: Judge 3; AI: Agreement Index (\%); EF: Executive Functions. Likert Scale (0 $=$ inadequate, $1=$ partially adequate, $2=$ adequate $)$.

After the analysis of judges, the material was revised in order to consider the suggestions. Then, the final version of the NRP included: changes in graphic aspects; more detailed descriptions for figures (materials), reading comprehension parameters (EFRE), and sessions (EFCOM). 
Table 5. Intra- and inter-judge agreement index (\%) for the modules of the neuropsychological rehabilitation program.

\begin{tabular}{|c|c|c|c|c|}
\hline Psychoeducation & $\mathrm{J} 1$ & $\mathrm{~J} 2$ & $\mathrm{~J} 3$ & AI \\
\hline Theoretical justification & 2 & 2 & 2 & 100 \\
\hline Session description & 2 & 2 & 2 & 100 \\
\hline Session division & 1 & 2 & 2 & 67 \\
\hline Materials used & 2 & 2 & 2 & 100 \\
\hline EF engagement & 2 & 2 & 2 & 100 \\
\hline Coherence with objectives & 2 & 2 & 2 & 100 \\
\hline Relation with other modules & 2 & 2 & 2 & 100 \\
\hline Ecological value & 2 & 2 & 2 & 100 \\
\hline Total $f(\%)$ & $15(94)$ & $16(100)$ & $16(100)$ & \\
\hline Orientation & $\mathrm{J} 1$ & $\mathrm{~J} 2$ & J3 & AI \\
\hline Theoretical justification & 2 & 2 & 2 & 100 \\
\hline Session description & 2 & 2 & 2 & 100 \\
\hline Session division & 2 & 2 & 2 & 100 \\
\hline Materials used & 2 & 2 & 2 & 100 \\
\hline EF engagement & 2 & 2 & 2 & 100 \\
\hline Coherence with objectives & 2 & 2 & 2 & 100 \\
\hline Relation with other modules & 2 & 2 & 2 & 100 \\
\hline Ecological value & 2 & 2 & 2 & 100 \\
\hline Total $f(\%)$ & $16(100)$ & $16(100)$ & $16(100)$ & \\
\hline EF applied to study competences & $\mathrm{J} 1$ & $\mathrm{~J} 2$ & $\mathrm{~J} 3$ & AI \\
\hline Theoretical justification & 2 & 2 & 2 & 100 \\
\hline Session description & 2 & 1 & 2 & 67 \\
\hline Session division & 2 & 2 & 2 & 100 \\
\hline Materials used & 2 & 2 & 2 & 100 \\
\hline EF engagement & 2 & 2 & 2 & 100 \\
\hline Coherence with objectives & 2 & 2 & 2 & 100 \\
\hline Relation with other modules & 2 & 2 & 2 & 100 \\
\hline Ecological value & 2 & 2 & 2 & 100 \\
\hline Total $f(\%)$ & $16(100)$ & $15(94)$ & $16(100)$ & \\
\hline EF applied to reading comprehension & $\mathrm{J} 1$ & $\mathrm{~J} 2$ & $\mathrm{~J} 3$ & AI \\
\hline Theoretical justification & 2 & 2 & 2 & 100 \\
\hline Session description & 2 & 2 & 2 & 100 \\
\hline Session division & 2 & 1 & 2 & 67 \\
\hline Materials used & 2 & 2 & 2 & 100 \\
\hline EF engagement & 2 & 2 & 2 & 100 \\
\hline Coherence with objectives & 2 & 2 & 2 & 100 \\
\hline Relation with other modules & 2 & 2 & 2 & 100 \\
\hline Ecological value & 2 & 2 & 2 & 100 \\
\hline Total $f(\%)$ & $16(100)$ & $15(94)$ & $16(100)$ & \\
\hline
\end{tabular}

Note. J1: Judge 1; J2: Judge 2; J3: Judge 3; AI: Agreement Index (\%); EF: Executive Functions. Likert Scale $(0=$ inadequate, $1=$ partially adequate, $2=$ adequate $)$. 


\section{Discussion}

The central goal of the program is to stimulate EF in students with DD. In addition, the program should promote behavior self-regulated, especially for study competencies (time management, organization of the study environment and materials, homework, note-taking, and preparing for exams) and reading comprehension. The target public should minimally have basic proficiency in reading or have already been subjected to some written language intervention. Therefore the neuropsychological rehabilitation program described in the present study does not exclude or replace phonological intervention. Individuals at this reading level (Frith, 1990) have greater control of phonologic strategies, that is, they tend to have better performance in decoding written material (graph-phonemic conversion). Thus, in a clinical intervention, it is possible to favor work on reading comprehension in its metacognitive aspects, according previous studies (Gersten et al., 2001; Mason, 2004; Antoniou, \& Souvignier, 2007; Roberts et al., 2008; Edmonds et al., 2009; Berkeley, Mastropieri, \& Scruggs, 2011; Solis et al., 2012; Zentall \& Lee, 2012; Mason, 2013; Cirino et al., 2016).

The initial phase in the elaboration of the NRP started from two assumptions. First, that intervention would target individuals with neurodevelopmental disorders, that is with persistent cognitive deficits. Thus the NR focus would not be a functional reconstitution per se (Ginarte-Aria, 2002), but the development of compensatory strategies (Ginarte-Aria, 2002; Cicerone et al., 2011). We chose the term neuropsychological rehabilitation because of its wide reach regarding the use of different techniques to help patients deal with their deficits (Cicerone et al., 2011). In this context, the current program can be differentiated from cognitive trainings aimed at the systematic stimulation of a single EF component (Karbach \& Unger, 2014; Holmes \& Gathercole, 2013; Karbach, Strobach, \& Schubert, 2015). Moreover, based on the international classification of functioning, disability and health (ICF) of the World Health Organization (WHO), rehabilitation should reduce the functional consequences of neurological losses. i.e., the impact of difficulties that individuals might have in performing specific tasks, e.g., school-related tasks (Loschiavo-Alvares et al., 2011).

The second assumption is associated with the way rehabilitation is put in practice. Because the EF represent a multifactorial construct related to objective-guided activities (Diamond, 2013; Bombín-Gonzalez et al., 2014), no specific tasks were planned to train each one of its components. Rather, we sought the engagement of different EF components to reach objectives defined during each session: establishing goals, planning, prioritizing, organizing, selecting and using strategies, monitoring one's own performance and self-evaluating.

Thus, the patient should be submitted to the clinical environment of EF strategies learning to deal with school demands. Moreover, he or she had the opportunity to be monitored in the use of these strategies in different contexts until the independent practice. This process of strategy internalization is recommended by the different models of self-regulated learning (Zimmerman, 2002; Pin- 
trich, 2000; Rosário, 2004), and EF intervention (Dawson \& Guare, 2010; Mason et al., 2012; Harris et al., 2012). In addition, as currently believed, the NR must produce changes in areas that are important to a patient's daily life, that is, it must have ecological value (Wilson, 2013; Rosenblum, Frisch, Deutsh-Castel, \& Josman, 2014).

The theoretical foundations and clinical principles of NPR were formed by selected models of clinical and educational areas. Some general clinical and methodological aspects were taken into account (López-Luengo, 2001; GinarteArias, 2002): adaptability of the NR to patient needs; family involvement; accounting for intervenient variables; beginning from nuclear aspects associated to the pertinent cognitive functions that are close to daily tasks; beginning with tasks that require less attention; favoring the use of daily materials with different sources of stimuli; seeking motivating materials; organizing tasks in a hierarchical manner and according to the patient's abilities; including instructive components and metacognitive training, while explaining the concept of stimulated function, and the strategies to develop it; giving feedback on performance, acknowledging success; controlling efficacy with regular record-keeping and use of instruments to evaluate the perception of clinical evolution.

Additionally, the selected educational models of self-regulated learning predict three phases for the resolution of a task, engaging different EF components in each one of them: planning (task analysis), execution (acting, monitoring, and controlling) and evaluation (self-reflection) (Pintrich, 2000; Zimmerman, 2002; Rosário, 2004). The steps defined in the SRSD model (Graham e Harris, 1996; Mason et al., 2012; Harris et al., 2012) were also taken into account for strategy learning, and should ensure that the patient acquires three types of knowledge: 1) Declarative-the patient must know the strategy and its objective; 2) Conditional-the patient must know when to use it; 3) Procedural-the patient must know how to use it and what are the available procedures (Rosário, 2004; Meltzer, 2007; Mason et al., 2012; Harris et al., 2012). This model of educational intervention was selected because it is conceptually close to what is understood as EF in neuropsychology and because there is evidence of its effectiveness in individuals with LD (Troia \& Graham, 2002; Mason, 2004; García-Sánchez \& Fidalgo-Redondo, 2006; Mason et al., 2012; Mason, 2013).

Regarding intervention in reading comprehension, we selected the metacognition model of Flavel (1979). In this model, metacognition is understood as the capacity for self-monitoring and self-regulation of psychological processes (cognitive, affective and conduct) (Flavell, 1979; 1987). The origin of this concept lies in the paradigm of information processing that describes executive mechanisms of learning, through the development of self-regulation. According to this author, an individual's metacognitive knowledge may be associated with: 1) Personal variables-knowledge acquired about the individual's abilities, difficulties and motivations; 2) Task variables-knowledge of different task demands; and 3) Strategy variables-knowledge of the repertoire of cognitive and metacognitive strategies (Flavell, 1987). 
As demonstrated by the analysis judges, results suggest that initial NPR parameters were adequate as a proposed intervention for dyslexia. However, suggestions were given by them for some items evaluated. Consequently, the final version includes more detailed explanations of materials and sessions.

Concerning modules, judge 1 suggested that a longer time should be dedicated to the psychoeducation. This concept can be understood as a systematic therapeutic procedure, often associated with psychotherapy or rehabilitation, which aims at informing patient and family about a given disorder and treatment forms (Lukens \& McFarlane, 2004). In the present work, we followed an informative model and planned one session with parents, one with the school and two with the patient. Based on the recommendation of judge 1, this module could be expanded depending on the profile of each family and patient.

Judge 2 referred that more detailed instructions should be included to clinical management when the patient does not complete at home the activities planned. Completing these activities translates into exercising strategies learned during the sessions, which is crucial for the patient to become independent in strategy use under different contexts. When an activity is programmed, the therapist should verify its completion at the beginning of the following session, to monitor the process of strategy acquisition, answer questions, and offer new instructions or training opportunities. Thus, through feedback, the therapist has a reinforcing role for the patient. Analyzing the variables that might explain why the patient did not complete a given task should be performed with the patient. Factors such as lack of motivation, difficulties in understanding the task and strategy use, poor use of time, forgetfulness, among others may represent target behaviors of therapist intervention, considering associations with proper executive functioning, goal of the NRP.

Additionally, strategic instruction should prioritize the development of self-reinforcement, that is, the patient's ability to select his or her own reinforcements after reaching a goal, engaging the EF more significantly. This procedure should be introduced and monitored by the therapist so that the patient acquires autonomy in the identification of reinforcing factors in the familiar and school contexts (Dawson \& Guare, 2010; Mason et al., 2012).

Judge 2 also suggested that a greater number of sessions should be designated to finalizing the NRP. The final version of NPR contemplated this aspect taking into account the clinical profile of each patient.

For the EFRE, the Cloze test was chosen as a procedure to monitoring performance and use of the learned strategies. This method, originally developed by Taylor (1953), involves omitting words from the text. After reading, the patient should complete the text based on what he or she has understood. The Cloze test, widely used for the evaluation and interventions in reading comprehension, is based on principles of cognitive psychology. In addition to language, the technique stimulates different cognitive domains, such as long-term and working memories. Depending on the difficulty of omitted words, different abilities are engaged, because the individual must make use of cognitive and meta-cognitive 
strategies to solve the problem. Thus, reading comprehension rescues prior knowledge, induces inferences and analogies (Santos, Primi, Taxa, \& Vendrami$\mathrm{ni}, 2002$ ). The type of narrative texts chosen for the NRP is usually easier for individuals with learning disorders, because its content is familiar, the text structure is simpler and it is the first type of text that children learn (Gersten et al., 2001).

It is evident that interventions specifically targeting the EF, within an ecological perspective, should incorporate tasks that offer distinct demands on EF components. In this context, the rehabilitation model proposed here differs from cognitive training methods of EF components, such as the working memory, widely used in neuropsychology with positive effects on academic performance (see Holmes \& Gathercole, 2013 for Cogmed; see Karbach et al., 2015 for Braintwister).

In planning interventions for specific populations, such as individuals with dyslexia, it is plausible that proposed tasks are associated with crucial difficulties. In this proposal, we emphasize reading and school situations in which students must use this ability. Justifying this choice, numerous studies show that the EF are good predictors of performance in school activities and reading comprehension (for a review, see Swanson \& Alloway, 2012), and, consequently, the effects of intervention can be noted in different neuropsychological and academic parameters (Holmes \& Gathercole, 2013; Karbach et al., 2015).

Long term effects or effect on cognitive domains that were not trained represent pertinent aspects for the evaluation of the efficacy of NR programs, or cognitive trainings. In this sense, the proposed NRP must be applied to dyslexia patients, using analyses that compare neuropsychological measures of ecological and non-ecological EF tests, and of reading comprehension. Because the NRP should promote learning of EF strategies, reports from patients, parents, and teachers on the frequency with which these strategies are adopted should provide an important parameter to assess efficacy. The use of statistical methods, developed in the context of neuropsychology (Crawford \& Garthwaite, 2012), for the comparison of intra- and inter-subject performances should adequately fit this objective.

\section{Conclusion}

The present work describes procedures for the development of a novel program for neuropsychological rehabilitation and stimulation of the EF in students with DD. Initial evaluation by three expert judges was satisfactory for the analyzed parameters: theoretical basis, clinical principles, materials and four modules. Further studies should be conducted to evaluate the efficacy of the program using neuropsychological measures of the EF and reading comprehension.

\section{Acknowledgements}

The authors thank the professionals who participated as judges in the evaluation of the neuropsychological rehabilitation program. 


\section{Funding}

RFL received a Capes (Coordination for the Improvement of Higher Education Personnel) scholarship (CAPES, 01P4353/2015) for doctoral degree in Medical Sciences at the State University of Campinas (UNICAMP).

\section{References}

Abreu, P. M. J. E., Abreu, N., Nikaedo, C. C., Puglisi, M. L., Tourinho, C. J., Miranda, M. C., Befi-Lopes, D. M., Bueno, O. F. A., \& Martin, R. (2014). Executive Functioning and Reading Achievement in School: A Study of Brazilian Children Assessed by Their Teachers as "Poor Readers". Frontiers in Psychology, 5, 1-14.

Antoniou, F., \& Souvignier, E. (2007). Strategy Instruction in Reading Comprehension: An Intervention Study for Students with Learning Disabilities. Learning Disabilities: $A$ Contemporary Journal, 5, 41-57.

Berkeley, S., Mastropieri, M. A., \& Scruggs, T. E. (2011). Reading Comprehension Strategy Instruction and Attribution Retraining for Secondary Students with Learning and Other Mild Disabilities. Journal of Learning Disabilities, 44, 18-32. https://doi.org/10.1177/0022219410371677

Bombín-González, I., Cifuentes-Rodríguez, A., Climent-Martínez, G., Luna-Lario, P., Cardas-Ibáñez, J., Tirapu-Ustárroz, J., \& Díaz-Orueta, U. (2014). Validez ecológica y entornos multitarea en la evaluación de las funciones ejecutivas. Revista de Neurología, 59, 77-87.

Bjork, R. A., Dunlosky, J., \& Kornell, N. (2013). Self-Regulated Learning: Beliefs, Techniques, and Illusions. Annual Review of Psychology, 64, 417-444. https://doi.org/10.1146/annurev-psych-113011-143823

Cicerone, K. D., Langenbahn, D. M., Braden, C., Malec, J. F., Kalmar, K., Fraas, M., Felicetti, T., Laatsch, L., Harley, J. P., Bergquist, T., Azulay, J., Cantor, J., \& Ashman, T. (2011). Evidence-Based Cognitive Rehabilitation: Updated Review of the Literature from 2003 through 2008. Archives of Physical Medicine and Rehabilitation, 92, 519 530. https://doi.org/10.1016/j.apmr.2010.11.015

Cirino, P. T., Miciak, J., Gerst, E., Barnes, M. A., Vaughn, S., Child, A., Huston-Warren, E. (2016). Executive Function, Self-Regulated Learning, and Reading Comprehension: A Training Study. Journal of Learning Disabilities, 8, 1-18. https://doi.org/10.1177/0022219415618497

Crawford, J. R., \& Garthwaite, P. H. (2012). Single-Case Research in Neuropsychology: A Comparison of Five Forms of t-Test for Comparing a Case to Controls. Cortex, 48, 1009-1016.

Dawson, P., \& Guare, R. (2010). Executive Skills in Children and Adolescent: A Practical Guide to Assessment and Intervention (2th ed.). New York, NY: The Guilford Press.

Diamond, A. (2013). Executive Functions. Annual Review of Psychology, 64, 135-168. https://doi.org/10.1146/annurev-psych-113011-143750

Edmonds, M. S., Vaughn, S., Wexler, J., Reutebuch, C., Cable, A., Tackett, K. K., \& Schnakenberg, J. W. (2009). A Synthesis of Reading Interventions and Effects on Reading Comprehension Outcomes for Older Struggling Readers. Review of Educational Research, 79, 262-300. https://doi.org/10.3102/0034654308325998

Flavell, J. H. (1979). Metacognition and Cognitive Monitoring: A New Area of Cognitive-Developmental Inquiry. American Psychologist, 34, 906-911. https://doi.org/10.1037/0003-066X.34.10.906

Flavell, J. H. (1987). Speculation about the Nature and Development of Metacognition. In 
F. E. Weinert, \& R. H. Kluwe (Eds.), Metacognition, Motivation, and Understanding (pp. 21-29). Mahwah, NJ: Lawrence Erlbaum Associates.

Fleiss, J. (1981). Statistical Methods for Rates and Proportions (2th ed.). New York, NY: John Wiley \& Sons.

Frith, U. (1990). Dyslexia as a Developmental Disorder of Language. London: MRC, Cognitive Development Unit.

García-Sánchez, J. N., \& Fidalgo-Redondo, R. (2006). Effects of Two Types of Self-Regulatory Instruction Programs on Students with Learning Disabilities in Writing Products, Processes, and Self-Efficacy. Learning Disability Quarterly, 29, 181-211. https://doi.org/10.2307/30035506

Gersten, R., Fuchs, L. S., Williams, J. P., \& Baker, S. (2001). Teaching Reading Comprehension Strategies to Students with Learning Disabilities: A Review of Research. Review of Educational Research, 71, 279-320. https://doi.org/10.3102/00346543071002279

Ginarte-Arias, Y. (2002). Rehabilitación cognitiva. Aspectos teóricos y metodológicos. Revista De Neurologia, 35, 870-876.

Graham, S., \& Harris, K. R. (1996). Addressing Problems in Attention, Memory, and Executive Functioning: An Example from Self-Regulated Strategy Development. In R. Lyon, \& N. Krasnegor (Eds.), Attention, Memory, and Executive Function. Baltimore: Brookes.

Harris, K. R., Graham, S., Mason, L. H., \& Friedlander, B. (2012). Powerful Writing Strategies for All Students. Baltimore: Paul H Brooks.

Hernández-Nieto, R. A. (2002). Contributions to Statistical Analysis. Mérida: Universidad de Los Andes.

Holmes, J., \& Gathercole, S. E. (2013). Taking Working Memory Training from the Laboratory into Schools. Educational Psychology, 34, 440-450.

https://doi.org/10.1080/01443410.2013.797338

Karbach, J., Strobach, T., \& Schubert, T. (2015). Adaptive Working-Memory Training Benefits Reading, But Not Mathematics in Middle Childhood. Child Neuropsychology, 21, 285-301. https://doi.org/10.1080/09297049.2014.899336

Karbach, J., \& Unger, K. (2014). Executive Control Training from Middle Childhood to Adolescence. Frontiers in Psychology, 5, 1-14. https://doi.org/10.3389/fpsyg.2014.00390

Kaufman, C. (2010). Executive Function in Classroom: Practical Strategies for Improving Performance and Enhancing Skills for All Students. Baltimore: Paul H Brookes.

Kim, W., Linan-Thompson, S., \& Misquitta, R. (2012). Critical Factors in Reading Comprehension Instruction for Students with Learning Disabilities: A Research Synthesis. Learning Disabilities Research \& Practice, 27, 66-78. https://doi.org/10.1111/j.1540-5826.2012.00352.x

Klingner, J. K., Vaughn, S., \& Boardman, A. (2007). Teaching Reading Comprehension to Students with Learning Difficulties. New York, NY: The Guilford Press.

Liew, J. (2011). Effortful Control, Executive Functions, and Education: Bringing Self-Regulatory and Social-Emotional Competencies to the Table. Child Development Perspectives, 6, 105-111. https://doi.org/10.1111/j.1750-8606.2011.00196.x

Lima, R. F., Salgado Azoni, C. A., \& Ciasca, S. M. (2013). Attentional and Executive Deficits in Brazilian Children with Developmental Dyslexia. Psychology, 4, 1-6. https://doi.org/10.4236/psych.2013.410A001

López-Luengo, B. (2001). Orientaciones en Rehabilitación Cognitiva. Revista De Neurologia, 33, 383-387.

Lorusso, M. L., Facoetti, A., \& Bakker, D. J. (2011). Neuropsychological Treatment of 
Dyslexia: Does Type of Treatment Matter? Journal of Learning Disabilities, 44, 136149. https://doi.org/10.1177/0022219410391186

Lorusso, M. L., Facoetti, A., Paganoni, P., Pezzani, M., \& Molteni, M. (2006). Effects of Visual Hemisphere-Specific Stimulation versus Reading-Focused Training in Dyslexic Children. Neuropsychological Rehabilitation, 16, 194-212. https://doi.org/10.1080/09602010500145620

Loschiavo-Alvares, F. Q., Sediyama, C. Y. N., Rivero, T. S., Nicolato, R., Neves, F., Bueno, O. F. A., Corrêa, H., \& Malloy-Diniz, L. F. (2011). Tools for Efficacy's Assessment of Neuropsychological Rehabilitation Programs: A Systematic Review. Child Neuropsychiatry, $8,1-11$.

Lukens, E. P., \& McFarlane, W. R. (2004). Psychoeducation as Evidence-Based Practice: Considerations for Practice, Research, and Policy. Brief Treatment and Crisis Intervention, 4, 205-225. https://doi.org/10.1093/brief-treatment/mhh019

Lyon, G. R., Shaywitz, S. E., \& Shaywitz, B. A. (2003). Defining Dyslexia, Comorbidity, Teachers' Knowledge of Language and Reading: A Definition of Dyslexia. Annals of Dyslexia, 53, 1-14. https://doi.org/10.1007/s11881-003-0001-9

Mason, L. H. (2004). Explicit Self-Regulated Strategy Development versus Reciprocal Questioning: Effects on Expository Reading Comprehension among Struggling Readers. Journal of Educational Psychology, 96, 283-296.

https://doi.org/10.1037/0022-0663.96.2.283

Mason, L. H. (2013). Teaching Students Who Struggle with Learning to Think before, while, and after Reading: Effects of Self-Regulated Strategy Development Instruction. Reading \& Writing Quarterly, 29, 124-144. https://doi.org/10.1080/10573569.2013.758561

Mason, L. H., Reid, R., \& Hanagan, J. L. (2012). Building Comprehension in Adolescents. Baltimore: Paul H Brooks.

Meltzer, L. (2007). Executive Functions in Education: From Theory to Practice. New York, NY: The Guilford Press.

Meltzer, L., \& Krishnan, K. (2007). Executive Function Difficulties and Learning Disabilities. In L. Meltzer (Ed.), Executive Function in Education: From Theory to Practice. New York, NY: The Guilford Press.

Moura, O., Simões, M. R., \& Pereira, M. (2014). Executive Functioning in Children with Developmental Dyslexia. The Clinical Neuropsychologist, 3, 1-22.

Pasquali, L. (2013). Psicometria: Teoria dos testes na psicologia e na educação (5th ed.). São Paulo: Vozes.

Pintrich, P. R. (2000). The Role of Goal Orientation in Self-Regulated Learning. In M. Boekaerts, P. R. Pintrich, \& M. Zeidner (Eds.), Handbook of Self-Regulation. Cambridge, MA: Academic Press.

Roberts, G., Torgesen, J. K., Boardman, A., \& Scammacca, N. (2008). Evidence-Based Strategies for Reading Instruction of Older Students with Learning Disabilities. Learning Disabilities Research \& Practice, 23, 63-69. https://doi.org/10.1111/j.1540-5826.2008.00264.x

Rosário, P. S. L. (2004). Estudar o estudar: As (Des)venturas do Testas. Porto: Porto Editora.

Rosenblum, S., Frisch, C., Deutsh-Castel, T., \& Josman, N. (2014). Daily Functioning Profile of Children with Attention Deficit Hyperactive Disorder: A Pilot Study Using an Ecological Assessment. Neuropsychological Rehabilitation, 23, 1-17.

Santos, A. A. A., Primi, R., Taxa, F., \& Vendramini, C. M. M. (2002). O teste de Cloze na avaliação da compreensão em leitura. Psicologia Reflexão e Crítica, 15, 549-560. 
https://doi.org/10.1590/S0102-79722002000300009

Sesma, H. W., Mahone, E. M., Levine, T., Eason, S. H., \& Cutting L. E. (2009). The Contribution of Executive Skills to Reading Comprehension. Child Neuropsychology, 15, 232-246. https://doi.org/10.1080/09297040802220029

Schunk, D. H., \& Ertmer, P. A. (2000). Self-Regulation and Academic Learning: Self-Efficacy Enhancing Interventions. In M. Boekaerts, P. R. Pintrich, \& M. Zeidner (Eds.), Handbook of Self-Regulation. Cambridge, MA: Academic Press.

Sohlberg, M. M., \& Matter, A. C. (2010). Controle dos sintomas disexecutivos. In M. M. Sohlberg, \& A. C. Matter (Eds.) Reabilitação Cognitiva: Uma abordagem neuropsicológica integrada. São Paulo: Santos.

Solis, M., Ciullo, S., Vaughn, S., Pyle, N., Hassaram, B., \& Leroux, A. (2012). Reading Comprehension Interventions for Middle School Students with Learning Disabilities: A Synthesis of 30 Years of Research. Journal of Learning Disabilities, 45, 327-340. https://doi.org/10.1177/0022219411402691

Swanson, H. L., \& Alloway, T. P. (2012). Working Memory, Learning, and Academic Achievement. In K. R. Harris, S. Graham, T. C. Urdan, B. McCormick Christine, G. M. Sinatra, \& J. Sweller (Eds.), APA Educational Psychology Handbook, Vol. 1: Theories, Constructs, and Critical Issues (pp. 327-366). Washington DC: American Psychological Association.

Taylor, W. L. (1953). Cloze Procedure: A New Tool for Measuring Readability. Le Journal de Québec, 30, 415-433.

Troia, G. A., \& Graham, S. (2002). The Effectiveness of a Highly Explicit, Teacher-Directed Strategy Instruction Routine: Changing the Writing Performance of Students with Learning Disabilities. Journal of Learning Disabilities, 35, 290-305.

https://doi.org/10.1177/00222194020350040101

Varvara, P., Varuzza, C., Sorrentino, A. C. P., Vicari, S., \& Menguini, D. (2014). Executive Functions in Developmental Dyslexia. Frontiers in Human Neuroscience, 8, 1-8. https://doi.org/10.3389/fnhum.2014.00120

Visu-Petra, L., Cheie, L., Benga, O., \& Miclea, M. (2011).Cognitive Control Goes to School: The Impact of Executive Functions on Academic Performance. Procedia-Social and Behavioral Sciences, 11, 240-244.

Wilson, B. A. (2008). Neuropsychological Rehabilitation. Annual Review of Clinical Psychology, 4, 141-162. https://doi.org/10.1146/annurev.clinpsy.4.022007.141212

Wilson, B. A. (2013). Neuropsychological Rehabilitation: State of the Science. South African Journal of Psychology, 43, 267-277. https://doi.org/10.1177/0081246313494156

Zentall, S. S., \& Lee, J. (2012). A Reading Motivation Intervention with Differential Outcomes for Students at Risk for Reading Disabilities, ADHD, and Typical Comparisons: “Clever Is and Clever Does." Learning Disability Quarterly, 35, 248-259. https://doi.org/10.1177/0731948712438556

Zimmerman, B. J. (2002). Becoming a Self-Regulated Learner: An Overview. Theory into Practice, 41, 64-72. https://doi.org/10.1207/s15430421tip4102_2

Zimmerman, B. J., Bonner, S., \& Kovach, R. (2002). Understanding the Principles of Self-Regulated Learning. In B. J. Zimmerman, S. Bonner, \& R. Kovach (Eds.), Developing Self-Regulated Learners: Beyond Achievement to Self-Efficacy. Washington DC: American Psychological Association. 
Submit or recommend next manuscript to SCIRP and we will provide best service for you:

Accepting pre-submission inquiries through Email, Facebook, LinkedIn, Twitter, etc. A wide selection of journals (inclusive of 9 subjects, more than 200 journals)

Providing 24-hour high-quality service

User-friendly online submission system

Fair and swift peer-review system

Efficient typesetting and proofreading procedure

Display of the result of downloads and visits, as well as the number of cited articles Maximum dissemination of your research work

Submit your manuscript at: http://papersubmission.scirp.org/

Or contact psych@scirp.org 